\title{
IMPLEMENTASI PEMBELAJARAN KOOPERATIF TIPE SNOWBALL THROWING UNTUK MENINGKATKAN HASIL BELAJAR SISWA KELAS X TSM A PADA MATA PELAJARAN TEKNOLOGI DASAR OTOMOTIF DI SMK MUHAMMADIYAH PAKEM
}

\author{
Aji Wicaksono \\ Pendidikan Teknik Otomotif, Universitas Negeri Yogyakarta \\ Email: aji.wicaksono@gmail.com
}

\begin{abstract}
This study aimed to improve students' learning outcomes through the implementation of the cooperative learning of the Snowball Throwing type in Grade X of TSM A in the basic automotive technology subject at SMK Muhammadiyah Pakem. This was a classroom action research study. The research subjects were the students of Grade X of TSM A in the 2018/2019 academic year with a total of 30 students. The study was conducted in two cycles and each cycle consisted of four stages, namely planning, action, observation, and reflection. The data were collected using a learning outcome test in the form of an objective multiple choice test. The data were analyzed by the quantitative analysis method. The results of the study showed that the learning outcomes of the students of Grade X of TSM A in the Basic Automotive Technology subject could be improved through the implementation of the cooperative learning of the Snowball Throwing type. The criterion for the success in this study was that $75 \%$ of the students were able to achieve a minimum learning mastery score of 75 . The improvement of the learning outcomes was indicated by the improvement in the percentage of the learning outcome mastery in each cycle; in the pre-cycle it was $54.83 \%$, in Cycle I it was $70 \%$, and in Cycle II it was $86.66 \%$.
\end{abstract}

Keywords: Snowball Throwing, learning outcomes.

\begin{abstract}
Abstrak
Penelitian ini bertujuan untuk meningkatkan hasil belajar siswa melalui implementasi pembelajaran kooperatif tipe Snowball Throwing di kelas X TSM A pada mata pelajaran teknologi dasar otomotif di SMK Muhammadiyah Pakem. Penelitian ini merupakan jenis penelitian tindakan kelas (classroom action research). Subyek penelitian yang digunakan adalah siswa kelas X TSM A tahun ajaran 2018/2019 yang berjumlah 30 siswa. Penelitian dilaksanakan dalam dua siklus dan setiap siklus terdiri dari 4 tahapan yaitu tahap perencanaan, tahap tindakan, tahap pengamatan, dan tahap refleksi. Teknik pengumpulan data menggunakan tes hasil belajar siswa dengan bentuk tes objektif pilihan ganda. Metode yang digunakan untuk analisis data yaitu dengan metode analisis kuantitatif. Hasil penelitian menunjukan bahwa hasil belajar siswa kelas X TSM A pada mata pelajaran Teknologi Dasar Otomotif dapat ditingkatkan melalui implementasi pembelajaran kooperatif tipe Snowball Throwing. Kriteria keberhasilan dalam penelitian ini yaitu $75 \%$ siswa dapat mencapai nilai ketuntasan belajar minimal (KBM) 75. Peningkatan hasil belajar dibuktikan dengan meningkatnya presentase ketuntasan hasil belajar pada tiap siklus, yaitu presentase pada pra siklus sebesar $54,83 \%$, siklus I sebesar $70 \%$ dan siklus II sebesar $86,66 \%$.
\end{abstract}

Kata kunci: Snowball Throwing, hasil belajar. 


\section{PENDAHULUAN}

Pendidikan dipandang sebagai salah satu cara untuk meningkatkan kualitas sumber daya manusia yang berkualitas guna mendukung terciptanya tujuan pembangunan nasional, karena melalui pendidikan manusia mendapatkan pengetahuan, keterampilan, nilai-nilai dan sikap. Sehingga dapat berpikir lebih sistematis, lebih rasional dan lebih kritis terhadap segala permasalahan yang dihadapi. Pendidikan sangatlah penting untuk manusia dengan berpusat pada tujuan pendidikan nasional dan lembaga pendidikan merumuskan pembelajaran sebagai wujud dari kegiatan-kegiatan pendidikan di sekolah. Lembaga pendidikan tersebut terdiri dari lembaga pendidikan formal, lembaga pendidikan informal, dan lembaga pendidikan non formal. Untuk meningkatkan Sumber Daya Manusia (SDM), pendidikan formal merupakan pendidikan yang diselenggarakan di sekolah-sekolah pada umumnya. Jalur pendidikan memiliki jenjang tesendiri dengan tahapan dari pendidikan dasar, pendidikan menengah, dan pendidikan tingkat tinggi.

Sekolah Menengah Kejuruan (SMK) adalah pendidikan tingkat menengah yang setara dengan Sekolah Menengah Atas (SMA). Pendidikan kejuruan merupakan bagian dari sistem Pendidikan Nasional untuk menyiapkan lulusan guna memasuki dunia kerja dengan berbekal ilmu pengetahuan serta keahlian yang diperoleh demi kemajuan dirinya sendiri, masyarakat, serta bangsa dan negara. Dengan demikian siswa SMK pada dasarnya diharapkan untuk mampu menjadi cadangan sumber daya manusia yang unggul, berdaya saing tinggi, memiliki produktifitas yang tinggi, kreatif, inovatif serta siap untuk menghasilkan produk yang unggul dan berkualitas tinggi.

Permasalahan yang biasa muncul di akhir proses pembelajaran adalah hasil belajar. Guru perlu mengetahui masukan dan proses yang baik untuk mencapai hasil belajar yang optimal. Masukan yang dimaksud diantaranya yaitu kesiapan untuk mengikuti pembelajaran yang akan berlangsung, sedangkan proses pembelajaran adalah interaksi yang terjadi ketika pembelajaran berlangsung. Interaksi tersebut diantaranya memperhatikan penjelasan dari guru, bertanya jika materi yang disampaikan sulit dipahami, menjawab pertanyaan dan menanggapi jawaban dan mengerjakan tugas.

Guru dan siswa merupakan komponen vital dalam pembelajaran, karena mereka saling terkait satu sama lain dengan tugas dan peranan yang berbeda, guru bertugas memberikan pengetahuan dan siswa menerimanya. Mereka juga berperan penting dalam mensukseskan proses pembelajaran yang sedang dijalankan. Dalam proses pembelajaran guru tidak hanya berperan sebagai fasilitator tetapi pemberi arah, konsultan, dan sekaligus teman 
siswa (Yuswono, Martubi, Sukaswanto, \& Budiman, 2015). Dalam pembelajaran yang aktif siswa dituntut untuk berlatih, berpikir, dan terampil. Siswa juga harus berpartisipasi dalam proses pembelajaran dengan melibatkan diri dalam kegiatan sehingga secara fisik mereka merupakan bagian dari proses pembelajaran tersebut.

Penggunaan metode pembelajaran yang monoton tanpa ada inovasi metode pembelajaran akan menimbulkan rasa bosan pada diri siswa sehingga akan menghambat tercapainya tujuan pembelajaran. Metode pembelajaran merupakan salah satu faktor yang berperan dalam keberhasilan proses belajar mengajar. Pemilihan metode hendaknya disesuaikan dengan kompetensi dari mata pelajaran yang ada. Ketepatan metode pembelajaran yang diterapkan dalam proses pembelajaran diharapkan mampu menarik perhatian siswa.

Aktivitas belajar siswa merupakan aktivitas yang bersifat fisik dan mental. Aktivitas belajar yang dilakukan oleh siswa berpengaruh pada output proses pembelajaran (Wu, Siswanto, Suyanto, Sampurno, \& Tan, 2018). Keterlibatan siswa ditunjukan melalui partisipasi pada saat proses belajar mengajar. Hal tersebut bertolak belakang dengan fakta yang terjadi pada saat dilakukan observasi di SMK Muhammadiyah Pakem. Pada saat pembelajaran berlangsung siswa cenderung bersikap pasif. Banyak siswa yang tidak mau bertanya kepada guru meskipun mereka sebenarnya belum mengerti tentang materi yang disampaikan. Tetapi ketika guru bertanya bagian mana yang belum bisa dipahami siswa hanya diam, setelah guru memberi tugas barulah guru mengetahui bagian mana yang belum dipahami siswanya.

Kedisiplinan siswa memiliki peranan yang besar dalam pembelajaran di sekolah. Dengan sikap disiplin yang teratur dan sesuai peraturan yang ditetapkan di sekolah, maka siswa dapat belajar dengan baik. Oleh karenanya, apabila sikap tidak disiplin dilakukan oleh siswa, maka dapat berpengaruh pada proses belajarnya. Sehingga perhatian dari pihak sekolah terkait kedisiplinan sangat diperlukan untuk membentuk kepribadian siswa yang disiplin sikap dan disiplin waktu yang tentunya akan berdampak pada terciptanya lingkungan belajar yang sesuai dengan tujuan pendidikan di sekolah.

Berdasarkan hasil pengamatan dan wawancara di SMK Muhammadiyah Pakem mengenai pembelajaran Teknologi Dasar Otomotif di kelas X TSM A diketahui bahwa pada mata pelajaran tersebut metode pembelajaran yang diterapkan belum dapat menjadikan siswa untuk berpartisipasi aktif dalam proses pembelajaran. Penggunaan model pembelajaran yang monoton tanpa ada inovasi metode pembelajaran menyebabkan siswa kurang memperhatikan materi yang sedang disampaikan, bahkan terdapat 5 sampai 6 siswa yang bermain 
handphone. Pada mata pelajaran Teknologi Dasar Otomotif kelas X TSM A hanya ada beberapa siswa yang nampak memperhatikan dalam proses pembelajaran dan berdasarkan hasil nilai ulangan harian di kelas X TSM A dari 31 siswa masih terdapat 14 siswa yang belum mencapai Ketuntasan Belajar Minimal (KBM) 75.

Pada saat guru menyampaikan materi di papan tulis, guru kurang memperhatikan siswa yang ada di kelas. Hal demikian akan menyebabkan suasana belajar menjadi membosankan dan siswa cenderung memilih untuk tidak memperhatikan materi yang sedang disampaikan. Dalam proses pembelajaran di kelas X TSM A guru belum pernah menerapkan model pembelajaran kooperatif. Pembelajaran kooperatif merupakan pembelajaran dengan nuansa kebersamaan, diarahkan oleh guru dan difokuskan pada kelompok yang terdiri atas 46 siswa di dalamnya agar mereka bisa saling bekerja sama untuk memaksimalkan belajar. Masalah dalam penelitian ini adalah:

1. Metode pembelajaran yang diterapkan belum dapat menjadikan siswa untuk berpartisipasi aktif dalam proses pembelajaran. Metode pembelajaran merupakan salah satu faktor yang mempengaruhi tingkat keberhasilan pada proses pembelajaran, pemilihan metode yang tepat akan berdampak pada pencapaian tujuan belajar. Metode pembelajaran yang monoton tanpa ada inovasi metode pembelajaran akan menimbulkan rasa bosan pada diri siswa sehingga akan menghambat tercapainya tujuan pembelajaran. Hal ini menimbukan pertanyaan seberapa besar pengaruh metode pembelajaran terhadap hasil belajar siswa di sekolah.

2. Pada saat pembelajaran berlangsung siswa cenderung bersikap pasif. Banyak siswa yang tidak mau bertanya kepada guru meskipun mereka sebenarnya belum mengerti tentang materi yang disampaikan. Tetapi ketika guru bertanya bagian mana yang belum bisa dipahami siswa hanya diam, setelah guru memberi tugas barulah guru mengetahui bagian mana yang belum dipahami siswanya.

3. Sikap disiplin siswa saat proses pembelajaran masih belum sesuai dengan peraturan yang berlaku, terdapat 5 sampai 6 siswa yang mengoperasikan handphone saat proses pembelajaran berlangsung.

4. Model pembelajaran kooperatif khususnya Snowball Throwing belum pernah diterapkan dalam proses pembelajaran pada kelas X TSM A di SMK Muhammadiyah Pakem.

5. Hasil nilai ulangan harian pada mata pelajaran Teknologi Dasar Otomotif di kelas X TSM A dari 31 siswa masih terdapat 14 siswa yang belum mencapai Ketuntasan Belajar Minimal (KBM) yaitu 75 . 
Rumusan masalah dalam penelitian ini adalah, "Apakah hasil belajar siswa kelas X TSM A pada mata pelajaran Teknologi Dasar Otomotif di SMK Muhammadiyah Pakem dapat ditingkatkan melalui implementasi pembelajaran kooperatif tipe Snowball Throwing ? ". sedangkan tujuan penelitian ini yaitu untuk meningkatkan hasil belajar siswa melalui implementasi pembelajaran kooperatif Snowball Throwing di kelas X TSM A pada mata pelajaran Teknologi Dasar Otomotif di SMK Muhammadiyah Pakem.

\section{METODE PENELITIAN}

\section{Desain Penelitian}

Penelitian ini merupakan Penelitian Tindakan Kelas (Class Room Action Research). Siklus tahapan PTK berbentuk spiral dari siklus satu ke siklus berikutnya. Diawali dengan perencanaan (plan), dilanjutkan dengan tindakan (action), diikuti dengan pengamatan (observation) terhadap tindakan yang dilakukan dan selanjutnya adalah refleksi (reflection). Desain pada penelitian ini menggunakan model penelitian tindakan kelas dari Kemmis \& Mc Taggart (1998).

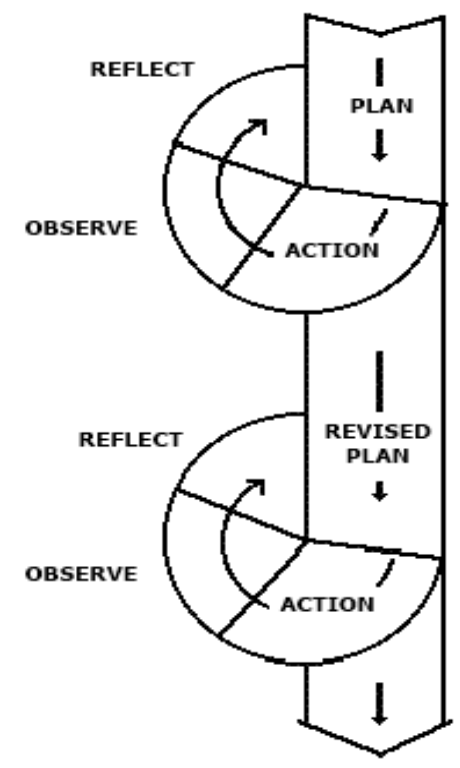

Gambar 1. Siklus PTK menurut Kemmis \& Mc Taggart. Sumber: Wijaya Kusumah (2010:21)

Desain penelitian ini berisi garis besar pelaksanaan penelitian tindakan kelas yang akan dilakukan. Penelitian tindakan kelas dilaksanakan dalam dua siklus yaitu siklus I dan siklus II. Setiap siklus terdiri dari dua kali pertemuan. Namun apabila dalam siklus I dan siklus II belum mencapai target yang diinginkan maka dapat dilaksanakan siklus selanjutnya. Sebelum melaksanakan siklus I perlu diadakanya tindakan pra siklus, untuk mengetahui kondisi belajar siswa dan menyusun kelompok. 


\section{Kegiatan Awal (Pra Siklus)}

Sebelum peneliti masuk dalam tindakan siklus I, perlu adanya kegiatan pra siklus. Kegiatan pra siklus berfungsi untuk memperoleh informasi mengenai keadaan sebelum diberikan tindakan. Kegiatan yang dilakukan pada tahap ini yaitu:

1) Menyamakan persepsi dengan guru dan observer mengenai teknis penerapan model pembelajaran kooperatif tipe Snowball Throwing, dan pembuatan soal untuk menilai hasil belajar siswa sebagai evaluasi pembelajaran. Guru berperan sebagai kolaborator yaitu bertindak sebagai pemberi materi kepada siswa.

2) Menyusun perangkat untuk pembelajaran berupa silabus, rencana pelaksanaan pembelajaran (RPP).

3) Menyusun dan mempersiapkan soal-soal untuk menilai kemampuan aspek kognitif pada mata pelajaran Teknologi Dasar Otomotif.

\section{Siklus I}

Siklus I dilakukan setelah tahap pra siklus dinyatakan selesai, telah dianalisis dan didapatkan hasil refleksinya. Hasil refleksi dari tahap pra siklus akan dijadikan sebagai inti dalam melaksanakan kegiatan siklus I. dalam siklus I dapat dijelaskan pokok kegiatan, yaitu:

1) Perencanaan (Plan)

Tahap perencanaan pada siklus I adalah merencanakan kegiatan yang akan dilakukan untuk memperbaiki masalah dari pembelajaran tersebut. Pada perencanaan hal yang paling utama adalah menyamakan persepsi antara peneliti dan guru agar pada saat pelaksanaan, peneliti dan guru pengampu mata pelajaran memiliki pemahaman yang sama dalam penerapan model pembelajaran kooperatif tipe Snowball Throwing.

2) Pelaksanaan Tindakan (Action)

Tahap ini merupakan pelaksanaan dari semua rencana yang telah dibuat. Seluruh tindakan dilakukan oleh guru sebagai kolaborator. Tindakan yang dilakukan adalah kegiatan berupa pembelajaran Teknologi Dasar Otomotif dengan menggunakan model pembelajaran kooperatif tipe Snowball Throwing.

3) Pengamatan (Observation)

Tahap observasi merupakan kegiatan pengamatan langsung terhadap pelaksanaan tindakan yang dilakukan dalam penelitian tindakan kelas, diantaranya peneliti mencatat seluruh 
proses kegiatan pembelajaran dari awal hingga akhir serta melakukan tes sesuai pedoman dan rencana yang sudah dibahas dengan guru.

4) Refleksi (Reflection)

Refleksi adalah kegiatan menganalisis, setelah dilaksanakannya tahap perencanaan, tindakan, dan pengamatan selesai, dan didapatkan data-data yang harus segera diolah sehingga dapat diputuskan tindakan apa saja yang akan dilakukan selanjutnya. Jika hasil data memenuhi target yang dicapai sesuai dengan indikator keberhasilan maka proses kegiatan bisa diberhentikan dan apabila belum memenuhi target sesuai dengan indikator keberhasilan maka penelitian tindakan dilanjutkan pada siklus berikutnya yang berguna sebagai perbaikan.

\section{Siklus II}

Kegiatan yang dilaksanakan pada siklus II dimaksudkan sebagai perbaikan dari siklus I. pelaksanaan siklus II sama dengan siklus I yaitu dimulai dari tahap perencanaan, pelaksanaan tindakan, pengamatan, dan refleksi.

\section{Lokasi dan Waktu Penelitian}

Penelitian ini dilaksanakan di kelas X TSM A SMK Muhammadiyah Pakem, Sleman yang beralamatkan di Jalan Pakem - Turi KM 0,5 Pakem, Sleman, Yogyakarta. Waktu penelitian dilaksanakan pada bulan Februari 2019 sampai dengan selesai sebanyak empat kali pertemuan dengan menggunakan siklus I dan siklus II. Namun apabila indikator keberhasilan tindakan belum tercapai maka akan dilanjutkan pada siklus selanjutnya.

\section{Subjek Penelitian}

Subjek pada penelitian ini adalah siswa kelas X TSM A SMK Muhammadiyah Pakem jurusan Teknik dan Bisnis Sepeda Motor tahun ajaran 2018/2019.

\section{Teknik Pengumpulan Data dan Instrument Penelitian}

Tes hasil belajar digunakan untuk mengukur hasil belajar teknologi dasar otomotif pada aspek kognitif, yaitu mengetahui sejauh mana siswa menguasai materi yang diajarkan. Pada penelitian ini menggunakan metode post test setelah diberi tindakan untuk mengukur peningkatan hasil belajar siswa. Bentuk tes yang dipilih adalah tes objektif pilihan ganda. Dipilihnya tes objektif pilihan ganda adalah karena tes memiliki kelebihan sebagai berikut dalam Sukiman (2011: 89): 
a. Jumlah materi yang dapat diujikan relatif banyak dibandingkan materi yang dapat dicakup soal bentuk lainnya. Jumlah soal yang ditanyakan umumnya relatif banyak

b. Dapat mengukur berbagai jenjang kognitif mulai dari ingatan sampai dengan evaluasi

c. Pengkoreksian dan penskorannya mudah, cepat, lebih objektif dan dapat mencakup ruang lingkup bahan dan materi yang luas dalam satu tes untuk suatu kelas atau jenjang

d. Sangat tepat untuk ujian yang pesertanya sangat banyak sedangkan hasilnya harus segera diketahui.

e. Reliabilitas soal pilihan ganda relatif lebih tinggi dibandingkan dengan soal uraian.

Tes hasil belajar yang digunakan adalah tes pilihan ganda yang terdiri dari suatu keterangan atau penjelasan tentang suatu materi yang belum lengkap. Untuk melengkapinya harus memilih satu dari beberapa kemungkinan jawaban yang telah disediakan. Tes pada penelitian ini adalah mengukur kompetensi peserta didik pada mata pelajaran Teknologi Dasar Otomotif dengan kompetensi dasar sistem hidraulik dan sistem pneumatik. Berikut ini merupakan indikator-indikator pada kompetensi dasar sistem hidraulik dan sistem pneumatik:

\begin{tabular}{|c|c|c|c|c|c|c|}
\hline \multirow{2}{*}{$\begin{array}{l}\text { Kompetensi } \\
\text { Dasar }\end{array}$} & \multirow{2}{*}{ Indikator } & \multicolumn{4}{|c|}{ Ranah Kognitif } & \multirow{2}{*}{$\begin{array}{l}\text { Jumlah } \\
\text { Soal }\end{array}$} \\
\hline & & C1 & $\mathrm{C} 2$ & C3 & $\mathrm{C} 4$ & \\
\hline \multirow{3}{*}{$\begin{array}{l}\text { 3.9.Memahami } \\
\text { dasar-dasar } \\
\text { sistem hidraulik }\end{array}$} & $\begin{array}{l}\text { 1. Menjelaskan prinsip } \\
\text { kerja sistem } \\
\text { hidraulik }\end{array}$ & 2 & 3 & 3 & 3 & 11 \\
\hline & $\begin{array}{l}\text { 2. Menjelaskan fungsi } \\
\text { sistem hidraulik }\end{array}$ & 3 & 4 & 2 & 2 & 11 \\
\hline & $\begin{array}{l}\text { 3. Menjelaskan simbol- } \\
\text { simbol sistem } \\
\text { hidraulik }\end{array}$ & 4 & - & - & - & 4 \\
\hline \multirow{3}{*}{$\begin{array}{l}\text { 3.10.Memahami } \\
\text { dasar-dasar } \\
\text { sistem } \\
\text { pneumatik. }\end{array}$} & $\begin{array}{l}\text { 1. Menjelaskan fungsi } \\
\text { sistem pneumatik }\end{array}$ & 2 & 4 & 3 & 2 & 11 \\
\hline & $\begin{array}{l}\text { 2. Menjelaskan prinsip } \\
\text { kerja kompresor }\end{array}$ & 2 & 4 & 2 & 2 & 10 \\
\hline & $\begin{array}{l}\text { 3. Menjelaskan simbol- } \\
\text { simbol sistem } \\
\text { pneumatik }\end{array}$ & 3 & - & - & - & 3 \\
\hline \multicolumn{2}{|r|}{ Jumlah } & 16 & 15 & 10 & 9 & 50 \\
\hline
\end{tabular}

Tabel 1. Format Kisi-kisi Instrumen Tes Hasil Belajar.

\section{Teknik Analisis Data}

Analisis tes hasil belajar siswa digunakan untuk mengukur sejauh mana pemahaman siswa mengenai materi yang telah disampaikan. Analisis terhadap tes hasil bellajar siswa dilakukan dengan analisis kuantitatif yaitu menentukan nilai rata-rata nilai tes. Rata-rata nilai tes diperoleh dari penjumlahan nilai yang diperoleh siswa selanjutnya dibagi dengan jumlah 
siswa yang ada di kelas tersebut. Pemberian skor tes didasarkan pada jumlah jawaban yang benar pada setiap siswa saat evaluasi.

Ketuntasan Belajar Minimal (KBM) pada mata pelajaran Teknologi Dasar Otomotif sesuai silabus yaitu 75. Apabila siswa sudah mencapai nilai 75 dan di atas 75-100, maka dinyatakan siswa tersebut sudah tuntas dan sebaliknya apabila nilai siswa di bawah 75 dapat dinyatakan siswa tersebut belum mampu mencapai nilai ketuntasan minimal.

Berikut rumus perhitungan rata-rata hasil belajar siswa menurut (Sudjana, 2014:109):

$$
\bar{X}=\frac{\Sigma x}{N}
$$

Keterangan:

$\bar{X}=$ Nilai rata-rata

$\Sigma x=$ Jumlah nilai seluruh siswa

$N=$ Jumlah siswa

Sedangkan rumus yang digunakan dalam menghitung persentase jumlah siswa yang dapat mencapai Ketuntasan Belajar Minimal (KBM) adalah sebagai berikut:

$$
\frac{\text { jumlah siswa yang mencapai KKM }}{\text { jumlah seluruh siswa }} \times 100 \%
$$

\section{HASIL PENELITIAN}

\section{Kegiatan Awal (Pra Siklus)}

Penelitian tindakan ini dilakukan di SMK Muhammadiyah Pakem pada kelas X TSM A dengan jumlah siswa pada saat observasi awal sebelum dilakukan tindakan sejumlah 31 siswa. Berdasarkan hasil pengamatan dan wawancara di SMK Muhammadiyah Pakem mengenai pembelajaran Teknologi Dasar Otomotif di kelas X TSM A diketahui bahwa pada mata pelajaran tersebut guru masih cenderung menggunakan model pembelajaran yang monoton. Pada mata pelajaran Teknologi Dasar Otomotif kelas X TSM A hanya ada beberapa siswa yang nampak memperhatikan dalam proses pembelajaran dan berdasarkan hasil nilai ulangan harian di kelas X TSM A dari 31 siswa masih terdapat 14 siswa atau 45,16\% yang belum mencapai Ketuntasan Belajar Minimal (KBM) 75, sedangkan rata-rata nilainya 65,6 dan nilai ulangan harian yang tertinggi 85 kemudian nilai terendah 40. Pada 
semester genap jumlah siswa berkurang menjadi 30 siswa dikarenakan satu siswa pindah kelas. Hasil selengkapnya untuk nilai ulangan harian siswa pada kompetensi dasar 3.7. Memahami proses dasar pembentukan logam, yang diadakan oleh guru di semester ganjil pada mata pelajaran Teknologi Dasar Otomotif kelas X TSM A dapat dilihat pada lampiran 11 yaitu tabel daftar nilai siswa.

Setelah diketahui banyaknya siswa yang belum mencapai nilai sesuai KBM 75, sebelum penelitian tindakan dilakukan terlebih dahulu menetapkan kompetensi dasar yang digunakan sebagai materi dalam pengimplementasian model pembelajaran kooperatif tipe Snowball Throwing. Kompetensi dasar yang dikaji berdasarkan rekomendasi guru yaitu kompetensi dasar 3.9 Memahami dasar-dasar sistem hidraulik dengan empat kali pertemuan pada siklus pertama dan kompetensi dasar 3.10 Memahami dasar-dasar sistem pneumatik dengan empat kali pertemuan pada siklus kedua, kemudian disusun rancangan pembelajaran berupa Rencana Pelaksanaan Pembelajaran (RPP). Pembuatan RPP dilakukan secara mandiri dengan dikonsultasikan kepada guru pengampu, konsultasi dilakukan supaya RPP benarbenar layak digunakan dalam proses pembelajaran dan mendapat persetujuan dari guru mata pelajaran Teknologi Dasar Otomotif.

Dalam kegiatan pra siklus peneliti menyiapkan instrumen penelitian tindakan yaitu berupa soal-soal pilihan ganda untuk mengukur kemampuan serta pemahaman siswa di akhir proses pembelajaran pada setiap siklus. Soal-soal tersebut disusun berdasarkan indikatorindikator dari kompetensi dasar yang telah di tetapkan. Selanjutnya instrumen tersebut divalidasi oleh dosen pembimbing dan guru pengampu mata pelajaran Teknologi Dasar Otomotif, langkah berikutnya menentukan waktu pelaksanaan penelitian tindakan berdasarkan kesepakatan guru sesuai dengan jadwal pelajaran yang diterapkan di sekolah.

\section{Siklus I}

Kegiatan pembelajaran siklus I pada mata pelajaran Teknologi Dasar Otomotif dilaksanakan dengan model pembelajaran kooperatif tipe Snowball Throwing. Siklus I dilaksanakan selama 4 kali pertemuan dengan jam pelajaran 2x45 menit setiap pertemuan. Pertemuan pertama pada siklus I dimulai pada tanggal 8 Januari, pertemuan kedua pada tanggal 9 januari 2019, pertemuan ketiga pada tanggal 15 Januari 2019, dan pertemuan keempat pada tanggal 18 Januari 2019 sesuai jadwal pelajaran yang telah ditetapkan. Pada siklus I materi yang diberikan yaitu kompetensi dasar 3.9. Memahami dasar-dasar sistem hridraulik. Proses pembelajaran dilaksanakan dengan menggunakan model pembelajaran 
kooperatif tipe Snowball Throwing. Penelitian tindakan ini mengacu pada desain penelitian menurut Kemmis \& Taggart yang terdiri dari tahap perencanaan, tindakan, Pengamatan, dan tahap refleksi. Berikut rincian dari setiap tahapan yang dilaksanakan:

\section{Perencanaan}

Pada perencanaan hal yang paling utama yaitu menyamakan persepsi antara peneliti dan guru agar pada saat pelaksanaan, peneliti dan guru pengampu mata pelajaran memiliki pemahaman yang sama dalam penerapan model pembelajaran kooperatif tipe Snowball Throwing. Selanjutnya setelah menyamakan persepsi antara peneliti dan guru maka peneliti menyiapkan instrumen dalam pembelajaran seperti silabus, rencana pelaksanaan pembelajaran, materi ajar, menyiapkan lembar kegiatan siswa/soal post test yang akan digunakan untuk mengukur hasil belajar siswa. Soal post test dengan bentuk pilihan ganda sejumlah 20 butir soal. Pada siklus I siswa belajar tentang dasar-dasar sistem hidraulik dengan diterapkan model pembelajaran Snowball Throwing.

\section{Tindakan}

Pelaksanaan pembelajaran pada siklus I dilaksanakan sebanyak 4 kali pertemuan dan alokasi waktu tiap pertemuan yaitu $2 \times 45$ menit. Proses pembelajaran dilaksanakan sesuai RPP yang telah disetujui oleh guru pengampu. Berikut uraian pembelajaran setiap pertemuan:

\section{Pertemuan Pertama}

Pertemuan pertama dilaksanakan pada tanggal 8 Januari 2019 di kelas X TSM A pada mata pelajaran Teknologi Dasar Otomotif. Berikut langkah-langkah pembelajaran yang dilaksanakan:

a) Pendahuluan

Pada tahap ini guru memberikan salam pembuka sebelum pembelajaran dimulai, dilanjutkan dengan melakukan presensi kehadiran siswa dan hasil presensi siswa diketahui 30 siswa hadir dan siap mengikuti pembelajaran. Kemudian guru menyampaikan tujuan pembelajaran dan pengantar mengenai pentingnya mempelajari dasar-dasar sistem hidraulik. Guru menyampaikan informasi kepada siswa tentang model pembelajaran yang akan digunakan dalam proses pembelajaran pada pertemuan pertama dan beberapa pertemuan yang akan datang dengan menggunakan model pembelajaran kooperatif tipe Snowball Throwing.

b) Kegiatan Inti

Guru menjelaskan materi tentang dasar-dasar sistem hidraulik kepada siswa kelas $\mathrm{X}$ TSM A. Kemudian guru membagi kelompok secara acak, setiap kelompok terdiri dari 5 
siswa dengan satu ketua kelompok. Setelah kelompok terkondisikan kemudian guru memanggil ketua kelompok untuk dijelaskan materi yang harus digunakan untuk menyusun pertanyaan. Ketua kelompok kembali ke kelompoknya masing-masing, kemudian menjelaskan materi yang disampaikan oleh guru kepada temannya. Masing-masing siswa diberi satu lembar kertas untuk menuliskan satu pertanyaan sesuai materi yang telah disampaikan oleh ketua kelompok.

c) Penutup

Pada tahap ini guru melakukan refleksi terhadap proses pembelajaran dengan cara menanyakan kesan-kesan dalam pembelajaran. Kemudian guru menjelaskan kegiatan belajar pada pertemuan selanjutnya dan di akhiri dengan menutup pertemuan dan berdoa.

\section{Pertemuan Kedua}

Pertemuan kedua dilaksanakan pada tanggal 9 Januari 2019 dengan alokasi waktu 2x45 menit. Berikut langkah-langkah pembelajaran yang dilaksanakan:

a) Pendahuluan

Guru memasuki ruangan dan memberikan salam kepada siswa dilanjutkan dengan presensi, pada hari tanggal tersebut siswa yang hadir sejumlah 30 siswa. Pada pertemuan kedua, guru menjelaskan tentang kelanjutan dari pertemuan yang sebelumnya yaitu melanjutkan materi pada pertemuan sebelumnya. Selanjutnya kertas yang berisi pertanyaan tersebut digulung dan dilempar ke siswa yang berbeda dengan kelompoknya selama 15 menit, setelah siswa mendapatkan satu bola kertas berisi pertanyaan maka siswa tersebut diharuskan menjawab secara bergantian. dan dilanjutkan dengan sesi menjawab pertanyaan yang sudah dibuat oleh masing-masing siswa di pertemuan sebelumnya.

b) Kegiatan Inti

Guru menjelaskan materi tentang dasar-dasar sistem hidraulik kepada siswa kelas X TSM A. Kemudian dilanjutkan dengan sesi menjawab pertanyaan yang ada pada gulungan kertas. Satu persatu siswa secara bergiliran menjawab pertanyaan dengan cara dikemukakan di depan kelas dalam waktu 3 menit. Dalam sesi ini guru juga mengoreksi atau membenarkan jawaban dari siswa yang belum tepat. Setelah siswa menjawab pertanyaan kemudian guru memberi kesempatan kepada siswa untuk bertanya tentang materi yang belum bisa di pahami. Ada 6 siswa yang bertanya mengenai materi yang belum dipahami, selanjutnya guru menjelaskan apa yang menjadi pertanyaan siswa-siswa tersebut. 
c) Penutup

Pada tahap ini guru melakukan refleksi terhadap proses pembelajaran dengan cara menanyakan kesan-kesan dalam proses pembelajaran menggunakan model pembelajaran kooperatif Snowball Throwing. Guru memberi informasi mengenai pertemuan yang akan dilaksanakan pada pertemuan selanjutnya dan pertemuan diakhiri dengan berdoa.

\section{Pertemuan Ketiga}

Pertemuan ketiga dilaksanakan pada tanggal 15 Januari 2019 dengan alokasi waktu 2x45 menit. Berikut langkah-langkah pembelajaran yang dilaksanakan:

a) Pendahuluan

Guru memasuki ruangan dan memberi salam kepada siswa dilanjutkan dengan presensi. Kemudian pada pertemuan ketiga, guru menjelaskan kelanjutan dari pertemuan sebelumnya yaitu melanjutkan sesi menjawab pertanyaan yang belum terjawab pada pertemuan sebelumnya.

b) Kegiatan Inti

Guru mengawali sesi dengan mempersilahkan siswa yang belum berkesempatan menjawab pertanyaan yang tertulis pada gulungan kertas. Satu persatu siswa secara bergiliran menjawab pertanyaan dengan cara dikemukakan di depan kelas dalam waktu 3 menit. Dalam sesi ini guru juga menanggapi atau membantu menjelaskan atas jawaban yang belum tepat. Setelah semua siswa menjawab pertanyaan kemudian guru memberi kesempatan kepada siswa untuk bertanya tentang materi yang belum bisa dipahami. Ada 6 siswa yang bertanya mengenai materi yang belum dipahami, selanjutnya guru menjelaskan apa yang menjadi pertanyaan siswa-siswa tersebut.

c) Penutup

Pada tahap ini guru menjelaskan kegiatan pembelajaran pada pertemuan selanjutnya yang akan diadakan post test dengan soal pilihan ganda yang terdiri dari 20 butir soal. Kemudian guru memberi arahan kepada siswa untuk mempersiapkan diri dengan belajar sebelum post test dilaksanakan. Guru menutup kegiatan pembelajaran dan diakhiri dengan berdoa.

\section{Pertemuan Keempat}

Pertemuan keempat dilaksanakan pada tanggal 18 Januari 2019 dengan alokasi waktu 2x45 menit. Berikut langkah-langkah pembelajaran yang dilaksanakan: 
a) Pendahuluan

Guru memasuki ruangan dan memberi salam kepada siswa dilanjutkan dengan presensi. Pada pertemuan ini siswa yang hadir berjumlah 27 siswa. Kemudian guru membagikan lembar soal beserta lembar jawab kepada siswa. Guru memberikan instruksi bahwa selama mengerjakan soal tidak boleh membuka catatan dan bekerja sama.

b) Kegiatan Inti

Pada tahap ini guru mengadakan post test dalam bentuk soal pilihan ganda sebanyak 20 butir soal. Alokasi waktu yang diberikan yaitu 60 menit. Guru mengawasi dan menegur siswa yang tidak mematuhi peraturan selama mengerjakan soal post test.

c) Penutup

Pada tahap penutup guru melakukan refleksi dengan mengadakan tanya jawab dari beberapa soal yang telah dikerjakan siswa. guru memberi informasi mengenai materi yang akan disampaikan pada pertemuan selanjutnya dan pertemuan diakhiri dengan berdoa.

\section{Pengamatan}

Dari hasil pengamatan proses pembelajaran berjalan sesuai rencana dengan penerapan model pembelajaran kooperatif tipe Snowball Throwing. Dari hasil observasi keterlaksanaan model pembelajaran dapat disimpulkan bahwa guru telah melaksanakan model pembelajaran Snowball Throwing dengan baik. Pada saat dilaksanakannya metode tersebut siswa tampak terlihat lebih aktif berinteraksi dengan anggota kelompok mendiskusikan jawaban-jawaban yang akan dikemukakan, walaupun ada beberapa siswa yang kurang percaya diri dalam menyampaikan jawaban di depan kelas. Evaluasi pembelajaran dilaksanakan pada akhir pertemuan keempat, dengan jumlah siswa yang hadir 27 siswa. soal yang digunakan untuk evaluasi pembelajaran berjumlah 20 butir soal pilihan ganda. Soal yang digunakan telah dipersiapkan sebelum penelitian dilaksanakan dan telah mendapat revisi dari dosen serta guru pengampu sehingga soal diperbaiki sampai layak untuk digunakan. Penilaian dilakukan sesuai pedoman pada RPP yaitu jumlah jawaban benar dikali 5. Berikut adalah hasil dari post test yang dilaksanakan dengan nilai Ketuntasan Belajar Minimal (KKM) 75, hasil belajar siswa kelas X TSM A pada siklus I menunjukan rata-rata nilai sebesar 69,5. Siswa yang tuntas sebanyak 21 siswa dan 9 siswa lainya tidak tuntas. Nilai tertinggi yang diperoleh siswa yaitu 90 dan nilai terendah 60. Adapun presentase ketuntasan dari seluruh siswa adalah 70\%. Dari hasil tersebut dinyatakan presentase ketuntasan siswa 
belum memenuhi indikator keberhasilan tindakan yaitu 75\%, sehingga perlu diadakan perbaikan pada siklus selanjutnya.

\section{Refleksi}

Berdasarkan perhitungan nilai hasil belajar siswa pada siklus I bahwa presentase ketuntasan siswa $70 \%$ dari total 30 siswa, sedangkan indikator keberhasilan penelitian yang harus dicapai yaitu 75\% siswa dapat mencapai nilai Ketuntasan Belajar Minimal yaitu 75. Dari hasil tersebut maka penelitian tindakan ini akan dilanjutkan pada siklus II. Pada siklus II proses pembelajaran tetap menggunakan model pembelajaran kooperatif tipe Snowball Throwing dengan beberapa perbaikan pada proses pembelajaran. Perbaikan yang dilakukan diantaranya melakukan persiapan yang lebih maksimal, memberi motivasi agar siswa lebih serius dalam belajar, menegur siswa yang membuat gaduh dalam kelompok, dan guru mendorong siswa agar percaya diri dalam menyampaikan pendapat dan jawaban dari pertanyaan yang diberikan oleh guru maupun temannya.

\section{Siklus II}

\section{Perencanaan}

Pada tahap perencanaan siklus II tindakan yang dilakukan yaitu memperbaiki kekurangan yang terjadi pada siklus I agar proses pembelajaran berjalan dengan baik dan indikator keberhasilan tindakan dapat tercapai. Adapun dalam tahap perencanaan ini peneliti dan guru lebih memaksimalkan persiapan sebelum proses pembelejaran berlangsung dan berdiskusi cara membenahi proses pembelajaran pada pertemuan sebelumnya. Kemudian menyiapkan instrumen pembelajaran seperti silabus, rencana pelaksanaan pembelajaran, materi ajar, lembar kegiatan siswa/soal post test yang akan digunakan untuk mengukur hasil belajar siswa. Pada siklus II siswa belajar tentang dasar-dasar sistem pneumatik dengan diterapkan model pembelajaran Snowball Throwing.

\section{Tindakan}

Pelaksanaan tindakan pada siklus II dilaksanakan sebanyak empat kali pertemuan masing-masing 2x45 menit. Pelaksanaan pembelajaran dilakukan sesuai dengan RPP yang telah disusun, berikut rincian setiap pertemuan:

\section{Pertemuan Pertama}


Pertemuan pertama dilaksanakan pada tanggal 22 Januari 2019 di kelas X TSM A pada mata pelajaran Teknologi Dasar Otomotif. Berikut langkah-langkah pembelajaran yang dilaksanakan:

a) Pendahuluan

Guru memasuki ruang kelas dan mengucapkan salam. Guru melakukan presensi siswa dan dari hasil presensi tersebut diketahui jumlah siswa yang hadir berjumlah 30 siswa. Guru memberi motivasi kepada siswa akan pentingnya belajar dasar-dasar sistem pneumatik dalam penerapannya di dunia kerja dan pendidikian. Guru menyampaikan informasi kepada siswa tentang model pembelajaran yang akan digunakan dalam proses pembelajaran pada pertemuan pertama dan beberapa pertemuan yang akan datang dengan menggunakan model pembelajaran kooperatif tipe Snowball Throwing dan dilanjutkan dengan menyampaikan tujuan pembelajaran.

b) Kegiatan inti

Guru menjelaskan materi tentang dasar-dasar sistem pneumatik kepada siswa kelas X TSM A. Guru memastikan bahwa siswa benar-benar paham akan materi yang telah dijelaskan yaitu materi tentang sistem pneumatik dan kompresor. Kemudian guru membagi kelompok secara acak, setiap kelompok terdiri dari 5 siswa dengan satu ketua kelompok. Setelah kelompok terkondisikan kemudian guru memanggil ketua kelompok untuk dijelaskan materi yang harus digunakan untuk menyusun pertanyaan. Masing-masing siswa diberi satu lembar kertas untuk menuliskan satu pertanyaan sesuai materi yang telah disampaikan oleh ketua kelompok. Dalam pelaksanaan pembelajaran guru menegur beberapa siswa yang membuat gaduh.

c) Penutup

Pada tahap ini guru melakukan refleksi terhadap proses pembelajaran dengan cara menanyakan kesan-kesan dalam pembelajaran. Kemudian guru menjelaskan kegiatan belajar pada pertemuan selanjutnya dan di akhiri dengan menutup pertemuan dan berdoa.

\section{Pertemuan Kedua}

Pertemuan kedua dilaksanakan pada tanggal 25 Januari 2019 dengan alokasi waktu 2x45 menit. Berikut langkah-langkah pembelajaran yang dilaksanakan:

a) Pendahuluan 
Guru memasuki ruangan dan memberikan salam kepada siswa dilanjutkan dengan presensi, pada hari tanggal tersebut siswa yang hadir berjumlah 30 siswa. Kemudian guru memberi arahan agar siswa lebih percaya diri dalam menyampaikan pendapat ataupun jawaban dari pertanyaan yag diberikan oleh guru maupun temannya.

b) Kegiatan Inti

Pada pertemuan kedua, guru menjelaskan tentang kelanjutan dari pertemuan yang sebelumnya yaitu melanjutkan materi pada pertemuan sebelumnya. Selanjutnya kertas yang berisi pertanyaan tersebut di gulung dan di lempar ke siswa yang berbeda dengan kelompoknya selama 15 menit, setelah siswa mendapatkan satu bola kertas berisi pertanyaan maka siswa tersebut diharuskan menjawab secara bergantian. Guru mengawali sesi dengan menunjuk siswa untuk menjawab pertanyaan yang tertulis dalam gulungan kertas. Guru kembali mengingatkan siswa agar lebih percaya diri dalam menjawab pertanyaan dan bertanya apabila ada hal yang belum dipahami. Dalam sesi ini guru juga mengoreksi atau membenarkan jawaban dari siswa yang belum tepat. Setelah beberapa siswa menjawab pertanyaan kemudian guru memberi kesempatan kepada siswa untuk bertanya tentang materi yang belum bisa di pahami.

c) Penutup

Pada tahap ini guru melakukan refleksi terhadap proses pembelajaran dengan cara menanyakan kesan-kesan dalam proses pembelajaran menggunakan model pembelajaran kooperatif Snowball Throwing. Guru memberi informasi mengenai pertemuan yang akan dilaksanakan pada pertemuan selanjutnya dan pertemuan diakhiri dengan berdoa.

\section{Pertemuan Ketiga}

Pertemuan ketiga dilaksanakan pada tanggal 29 Januari 2019 di kelas X TSM A pada mata pelajaran Teknologi Dasar Otomotif. Berikut ini langkah-langkah pembelajaran yang dilaksanakan:

a) Pendahuluan

Guru memasuki ruang kelas dan mengucapkan salam. Guru melakukan presensi siswa dan dari hasil presensi tersebut diketahui jumlah siswa yang hadir berjumlah 30 siswa.

b) Kegiatan Inti

Guru mengawali sesi dengan mempersilahkan siswa yang belum berkesempatan menjawab pertanyaan yang tertulis pada gulungan kertas. Satu persatu siswa secara bergiliran menjawab pertanyaan dengan cara dikemukakan di depan kelas dalam waktu 3 menit. Dalam 
sesi ini guru juga menanggapi atau membantu menjelaskan atas jawaban yang belum tepat. Setelah semua siswa menjawab pertanyaan kemudian guru memberi kesempatan kepada siswa untuk bertanya tentang materi yang belum bisa dipahami.

c) Penutup

Pada tahap ini guru menanggapi pertanyaan yang belum terjawab dengan benar dan melakukan refleksi terhadap proses pembelajaran dengan cara menanyakan kesan-kesan dalam pembelajaran dengan model Snowball Throwing yang telah dilaksanakan. Siswa merasa kegiatan pembelajaran yang dilaksanakan menggunakan model pembelajaran kooperatif menjadikan suasana belajar lebih menarik dan tidak menimbulkan rasa bosan. Pada tahap ini guru menjelaskan kegiatan pembelajaran pada pertemuan selanjutnya yang akan diadakan post test dengan soal pilihan ganda yang terdiri dari 20 butir soal. Kemudian guru memberi arahan kepada siswa untuk mempersiapkan diri dengan belajar sebelum post test dilaksanakan. Guru menutup kegiatan pembelajaran dan diakhiri dengan berdoa.

\section{Pertemuan Keempat}

Pertemuan keempat dilaksanakan pada tanggal 1 Februari 2019 dengan alokasi waktu 2x45 menit. Berikut langkah-langkah pembelajaran yang dilaksanakan:

a) Pendahuluan

Guru memasuki ruangan dan memberi salam kepada siswa dilanjutkan dengan presensi. Pada pertemuan ini siswa yang hadir berjumlah 30 siswa. Kemudian guru membagikan lembar soal beserta lembar jawab kepada siswa. guru memberikan instruksi bahwa selama mengerjakan soal tidak boleh membuka catatan dan bekerja sama.

b) Kegiatan Inti

Pada tahap ini guru mengadakan post test dalam bentuk soal pilihan ganda sebanyak 20 butir soal. Guru memberi instruksi bahwa dalam mengerjakan soal tidak boleh membuka catatan dan tidak boleh bekerja sama.

c) Penutup

Pada tahap penutup guru melakukan refleksi dengan mengadakan tanya jawab dari beberapa soal yang telah dikerjakan siswa. guru memberi informasi mengenai materi yang akan disampaikan pada pertemuan selanjutnya dan pertemuan diakhiri dengan berdoa. 


\section{Pengamatan}

Dari hasil pengamatan proses pembelajaran berjalan sesuai rencana dengan penerapan model pembelajaran kooperatif tipe Snowball Throwing. Berikut adalah hasil dari post test yang dilaksanakan dengan nilai Ketuntasan Belajar Minimal (KKM) 75, hasil belajar siswa kelas X TSM A pada siklus II menunjukan rata-rata nilai sebesar 81,83 . Siswa yang tuntas sebanyak 26 siswa dan 4 siswa lainya tidak tuntas. Nilai tertinggi yang diperoleh siswa yaitu 95 dan nilai terendah 65. Adapun presentase ketuntasan dari seluruh siswa adalah $86,66 \%$. Dari hasil tersebut dinyatakan presentase ketuntasan siswa telah memenuhi indikator keberhasilan tindakan yaitu $75 \%$, sehingga tidak perlu diadakan perbaikan pada siklus selanjutnya. Dari hasil pengamatan keterlaksanaan model pembelajaran kooperatif tipe Snowball Throwing pada siklus II menunjukan bahwa model pembelajaran tersebut sudah dilaksanakan sebagaimana mestinya. Pada pembelajaran siklus II siswa lebih percaya diri dalam menyampaikan pendapat. Model pembelajaran Snowball Throwing yang diterapkan membuat suasana belajar menjadi menarik dan tidak menimbulkan rasa bosan serta siswa lebih antusias memperhatikan materi yang disampaikan oleh guru.

\section{Refleksi}

Hasil penelitian tindakan implementasi pembelajaran kooperatif tipe Snowball Throwing secara keseluruhan menunjukan adanya peningkatan. Pada siklus II kegiatan pembelajaran berjalan dengan baik. Dari hasil pengamatan siklus II terdapat peningkatan hasil belajar secara signifikan dan jumlah siswa yang tuntas bertambah menjadi 26 siswa atau $86,66 \%$ dari total keseluruhan

siswa yang berjumlah 30 siswa. Secara keseluruhan hasil tersebut dinyatakan bahwa presentase ketuntasan siswa telah memenuhi indikator keberhasilan tindakan yaitu $75 \%$, sehingga penelitian tindakan dapat dihentikan.

\section{PEMBAHASAN}

Berdasarkan hasil penelitian tindakan menunjukan bahwa hasil belajar siswa kelas X TSM A pada mata pelajaran Teknologi Dasar Otomotif dapat ditingkatkan melalui implementasi pembelajaraan kooperatif tipe Snowball Throwing. Dengan adanya pembelajaran kooperatif tipe Snowball Throwing ini siswa dapat lebih memahami materi dalam proses pembelajaran, karena pembelajaran yang semula berpusat pada guru menjadi berpusat pada siswa. Hal tersebut dapat dilihat dengan meningkatnya hasil belajar siklus I dan siklus II. Hasil belajar diketahui dengan diadakannya post test pada akhir setiap siklus. Dilihat dari hasil belajar 
siswa terjadi peningkatan yang akhirnya pada siklus II telah mampu mencapai indikator keberhasilan yaitu 75\% siswa memiliki nilai di atas Ketuntasan Belajar Minimal (KBM) 75 .

Tabel 2. Peningkatan Hasil Belajar Siswa Pra Siklus, Siklus I dan Siklus II.

\begin{tabular}{cccc}
\hline Hasil Belajar Siswa & Pra Siklus & Siklus I & Siklus II \\
\hline Nilai Tertinggi & 85 & 90 & 95 \\
Nilai Terendah & 40 & 60 & 65 \\
Rata-rata & 65,6 & 69,5 & 81,83 \\
Jumlah siswa tuntas & 17 & 21 & 26 \\
Presentase Ketuntasan & $54,83 \%$ & $70 \%$ & $86,66 \%$ \\
\hline
\end{tabular}

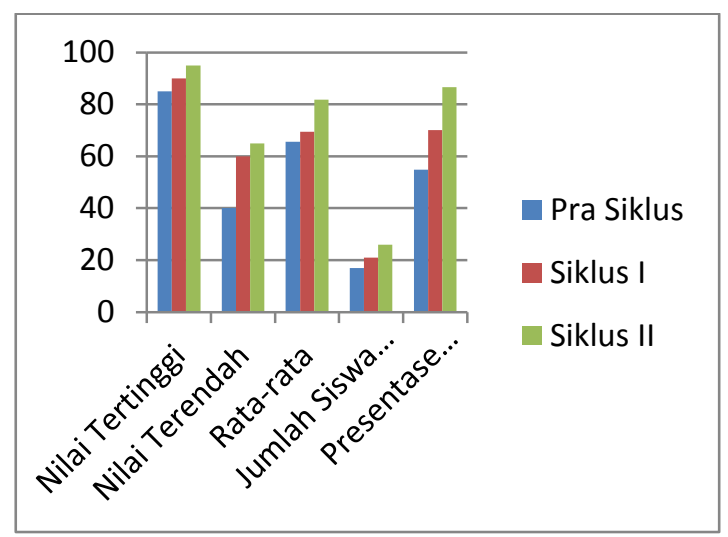

Gambar 2. Diagram Peningkatan Hasil Belajar Siswa pada setiap Siklus.

Berdasarkan tabel 6 dan gambar 5 diatas dapat diketahui bahwa rata-rata nilai hasil belajar pada pra siklus sebesar 65,6 dengan presentase ketuntasan 54,83\% dan jumlah siswa yang mencapai nilai KBM sebanyak 17 siswa. pada siklus I diperoleh data rata-rata nilai hasil belajar sebesar 69,5 dengan presentase ketuntasan 70\% dan jumlah siswa yang mencapai KBM sebanyak 21 siswa. kemudian pada siklus II rata-rata nilai hasil belajar sebesar 81,83 dengan presentase ketuntasan 86,66\% dan jumlah siswa yang mencapai KBM 26 siswa. Pelaksanaan pembelajaran kooperatif tipe Snowball Throwing pada siklus I berjalan sesuai dengan rencana meskipun dilihat dari hasil belajar siswa belum mencapai indikator keberhasilan penelitian tindakan. Pada siklus I hanya 21 siswa yang mencapai KBM 75, dengan nilai tertinggi 90 dan nilai terendah 60. Kemudian pada siklus II hasil belajar mengalami peningkatan, dilihat dari jumlah siswa yang mendapat nilai diatas KBM 75 berjumlah 26 dengan nilai tertinggi 95 dan nilai terendah 65 . 
Peningkatan hasil belajar pada penelitian ini menguatkan penelitian terdahulu yang dilakukan oleh Praptiningsih (2014) dengan judul "Peningkatan Keaktifan dan Hasil Belajar Siswa Kelas X Jasa Boga 3 melalui Penerapan Metode Pembelajaran Snowball Throwing pada Mata Pelajaran Pengetahuan Bahan Makanan di SMK N 3 Klaten”.

\section{SIMPULAN}

Berdasarkan hasil penelitian tindakan kelas yang telah dilakukan, maka dapat disimpulkan bahwa hasil belajar siswa kelas X TSM A pada mata pelajaran Teknologi Dasar Otomotif dapat ditingkatkan melalui implementasi pembelajaran kooperatif tipe Snowball Throwing. Peningkatan hasil belajar dibuktikan dengan meningkatnya presentase ketuntasan hasil belajar pada tiap siklus, yaitu presentase pada pra siklus sebesar 54,83\%, siklus I sebesar $70 \%$ dan siklus II $86,66 \%$. Guru dapat menerapkan model pembelajaran kooperatif tipe Snowball Throwing dalam proses pembelajaran sebagai salah satu alternatif dalam usaha untuk memperbaiki proses pembelajaran dengan mengembangkan berbagai bentuk kegiatan didalamnya agar pembelajaran lebih menarik dan bervariasi sehingga siswa tidak jenuh dan bosan.

\section{DAFTAR PUSTAKA}

Sudjana, N. (2014). Penilaian dan Hasil Belajar Mengajar. Bandung: Sinar Baru Algesindo Offset.

Praptiningsih. (2014). Peningkatan Keaktifan dan Hasil Belajar Siswa Kelas X Jasa Boga 3 melalui Penerapan Metode Pembelajaran Snowball Throwing pada Mata Pelajaran Pengetahuan

Wu, M., Siswanto, I., Suyanto, W., Sampurno, Y. G., \& Tan, W. (2018). Creative thinking curriculum infusion for students of teachers' education program. Jurnal Pendidikan Teknologi dan Kejuruan, 24(1), 1-12.

Yuswono, L. C., Martubi, Sukaswanto, \& Budiman, A. (2015). Profil Kompetensi Guru SMK Teknik Kendaraan Ringan di Daerah Istimewa Yogyakarta. Penelitianpendidikan, 438 . 
114 Aji Wicaksono 